Article

\title{
Rural Food and Wine Tourism in Canada's South Okanagan Valley: Transformations for Food Sovereignty?
}

\author{
Danielle Robinson 1,2
}

check for

updates

Citation: Robinson, D. Rural Food and Wine Tourism in Canada's South Okanagan Valley: Transformations for Food Sovereignty?. Sustainability 2021, 13, 1808. https://doi.org/ $10.3390 /$ su13041808

Academic Editor: Brian Garrod

Received: 18 January 2021

Accepted: 2 February 2021

Published: 7 February 2021

Publisher's Note: MDPI stays neutral with regard to jurisdictional claims in published maps and institutional affiliations.

Copyright: (C) 2021 by the author. Licensee MDPI, Basel, Switzerland. This article is an open access article distributed under the terms and conditions of the Creative Commons Attribution (CC BY) license (https:/ / creativecommons.org/licenses/by/ $4.0 /)$.
1 School of Business, Okanagan College, BC V1Y 4X8, Canada

2 Community, Culture and Global Studies, Irving K. Barber Faculty of Arts and Social Sciences, University of British Columbia Okanagan, Kelowna, V1V 1V7, Canada; danielle.robinson@ubc.ca

\begin{abstract}
This interdisciplinary research analyses the relationships between food sovereignty principles and food and wine tourism in rural contexts by asking how rural tourism stakeholders understand these concepts, mobilize the interrelationships, and to what purpose. Wine and food tourism is one of the fastest-growing rural tourism niches, with effects on the orientation of food systems, the livelihoods of producers, the viability of rural communities, and the biophysical environment. Secondary research and semi-structured interviews provide insights into how qualities of food sovereignty transitions are conceptualized, recognized, developed, supported, and promoted in the case of British Columbia's South Okanagan Valley. An appreciative approach was used because this research aims to understand rural food and wine tourism's potential contribution to food sovereignty. Although the term 'food sovereignty' did not resonate for most participants, qualities of a transition towards food sovereignty such as reorienting agriculture, food processing and consumption to the local region, supporting rural economies and environmental sustainability were considered integral to rural food tourism. Participants saw future opportunities for rural food and wine tourism to serve broader transformative purposes that would benefit locals, visitors, and the environment. Research results could be used to inspire critical academic, community and policy dialogue about food sovereignty in wine and food tourism destinations.
\end{abstract}

Keywords: rural tourism; Okanagan; food sovereignty; agritourism; wine tourism; food tourism; transformative tourism

\section{Introduction}

Rural communities in Canada are diverse, but agriculture continues to be the social and economic foundation of many of them. Despite or perhaps sometimes because of the challenges faced by rural communities, they are also home to great strengths, which include the ability to organize and educate Canadians about local and sustainable food systems. In fact, many food sovereignty strategies are grounded in the contemporary and historical practices of Canada's agricultural communities [1]. Rural food tourism's role as a food sovereignty strategy which connects rural and urban communities through a shared appreciation for environmentally sustainable and socially just food has not been deeply explored.

This research takes an appreciative approach to investigating the relationships between food sovereignty principles and tourism in rural agricultural contexts by asking how rural tourism actors in the South Okanagan Valley of British Columbia, Canada understand these concepts, mobilize the interrelationships, and to what purpose. First, relevant literature on food sovereignty and rural food tourism, which includes agritourism and wine tourism, are synthesized and opportunities identified. Second, the research case community is introduced. Third, the qualitative, appreciative research method is described. Fourth, results are thematically presented. Finally, the results are discussed in relationship to the existing literature and next steps are proposed. This research makes an important contribution because without improved understanding of the interrelationships between 
tourism and food sovereignty, it is impossible to proactively safeguard rural regions from the negative effects of tourism, or to foster the potential positive contributions that rural food tourism might make to food sovereignty transitions.

\subsection{Food Sovereignty}

With roots in the international peasants' movement, food sovereignty emerged as part of a "response to the failure of current approaches to alleviate the linked challenges of global food insecurity and environmental degradation" [2] (p. 174). The concept of food sovereignty has been taken up by a broad cross-section of social movements and non-governmental organizations including farmer organizations, Indigenous rights organizations, and environmental groups [3]. Food sovereignty movements frequently support the expansion of agroecology, which is generally understood as an ecology of food systems that includes innovative approaches to agroecosystem management and social action devoted to transformational food system change for sustainability [4-6]. The movement is not without contentious issues and internal disagreement [7-9]; however, there are six key themes evident in the food sovereignty literature: food for people, value for food providers, local food systems, local decision making, knowledge and skill building and work with nature [7].

\subsection{Rural Food Sovereignty}

Canadian rural agricultural communities face numerous distinct challenges related to food sovereignty such as declining farm incomes, higher food costs, fewer family owned farms and depopulation [1,10-12]. These challenges are related to the extensive changes in Canadian agriculture over the past 50 years as agriculture sought to maximize farm productivity through intensification, concentration, and specialization; these market-based approaches primarily benefited larger producers [13-15].

These productivist shifts in agricultural practices and policies decreased commodity prices and necessitated the further industrialization of agricultural activities to achieve greater economies of scale which further supports agri-food sector concentration [15-17], and has placed an economic strain on small family farm enterprises which have been the historic foundation of the rural economy in many Canadian regions [10,18]. While yields and gross farm revenue increased over the past three decades, farmers' share of that value has decreased significantly [19]. Local infrastructure and equipment are frequently lacking, making rural communities and smaller growers dependent upon highly centralized infrastructure for food production such as abattoirs and grain storage [16] and farmers are increasingly pressured to enlarge and corporatize, resulting in a decreasing number of farms [20].

High-volume, low-priced commodities such as canola, wheat and soybeans and foods with high costs, such as beef and seafood, are exported, while higher-value products such as wine, baked goods and produce are imported. As a result, Canada's food system loses biodiversity, becomes more export dependent, and forgoes lucrative opportunities to contribute value-added activities [21]. In addition, the pressure to maximize production under this model creates dependencies on technology and chemicals which degrade the natural environment [19] and make the food system more vulnerable to external pressures.

The types of crops that are grown and how the land is farmed in rural agricultural communities can be market-driven rather than serving community food needs [16]. Despite living near sites of food production, some rural people face systemic barriers that make this food inaccessible [8] (p. 919). Poverty is higher and food more expensive in rural areas and remote communities, making it more difficult for residents to afford nutritious store-bought food. Long distances to stores and a limited public transportation can aggravate the effect of poverty on food access [22]. Globalization has dramatically altered agriculture and rural agricultural communities. Rural tourism has been one response to these challenges. 


\subsection{Rural Tourism}

As rural communities struggled with economic, social, cultural, environmental, and political changes connected to globalization, tourism became an increasingly popular economic development mechanism [23,24]. Rural areas were perceived as having retained traditional landscapes and values, which appealed to urban residents who saw rural tourism as an escape from modernity and the physical and mental exhaustion of work [24-27].

Rural economic development through tourism operated within a neoliberal political and economic context that placed responsibility for economic growth with localities and relied on increasing entrepreneurship [24]. Tourism was recognized by rural communities, and by governments, as a valuable activity that offered rural regeneration benefits with manageable risks, particularly in areas with declining agriculture, resource extraction and industrial production [28]. It did not require intense capital investments, was built on existing local assets, and was largely small scale. Entrepreneurial opportunities in rural tourism began to attract new, often skilled and well-resourced lifestyle migrants from cities [29].

Tourism impacts are particularly acute and widespread because tourism turns the concepts of import and export 'on their heads' by importing people as its export [24]; therefore, unlike many other types of economic development, tourism development affects the entire community and their collective resources, regardless of whether they are directly involved in, or benefitting from, the development. Rural tourism can negatively impact the cultural, social, economic and environmental sustainability of rural communities. From air travel, to accommodation, to waste disposal, to infrastructure requirements, the negative environmental impacts from tourism-related activity are significant [24,30,31]. Many ecologically sensitive rural tourist destinations are at even greater risk of environmental degradation from tourist activity [32]. There can also be pressure that local environmental resources be sacrificed in efforts to satisfy market demands [33]. Tourism growth in rural areas can destroy the very culture, rurality and ecological diversity which attracts tourists $[34,35]$. Food tourism may seem small scale, but impacts on local food systems may be significant [36].

\subsection{Rural Food Tourism}

Food tourism, wine tourism and agritourism represent the fastest-growing rural tourism niches [37]; therefore, it is critical to better understand how they affect rural communities. Food tourism, wine tourism and agritourism are overviewed here with the understanding that these tourism types are often described in this paper under the inclusive term "rural food tourism." Then rural food tourism's relationship to food sovereignty priorities is considered.

Agritourism, which includes activities such as farm markets, wineries, U-Picks, farming interpretive centres, farm-based accommodation and harvest festivals [38], is considered an on-farm income diversification tactic that maintains farming activities and the agricultural landscape [38-41]. Agritourism emerged across numerous rural areas beginning in the 1970s as part of agricultural communities' response to the economic, social, cultural, environmental, and political effects of globalization [42].

Although drink is implied in the term food tourism, wine tourism is often treated as a distinct form of tourism. Wine tourism is the most widely researched sub-category of and predates research on food tourism [42]. Wine tourism commonly connects the wine product with the destination to create a cultural experience of "consuming place" [43]. Since most wine tourism in rural areas occurs at the cellar doors of farm wineries much wine tourism is agritourism. The amenity value of vineyard production reflects the productionconsumption convergence of a valuable crop and a valued cultural product. Consumption of wine, at the point of production, carries substantial class attachment [44,45].

Culinary tourism, gastronomy tourism, food tourism, food and drink tourism, and food and beverage tourism are equivalent terms that refer to a type of special interest 
tourism category [42] focused on food and beverage attractions. Food tourism may or may not be located on agricultural land, but always depends on agriculture. Food tourism now includes the full range of experiences, cooking classes, producer visits, enjoying street food, restaurants, wineries and brew pubs [46]. A frequently cited definition of food tourism which specifies food as a primary motivator is that of Hall and Mitchell (2001): "visitation to primary and secondary food producers, food festivals, restaurants and specific locations for which food tasting and/or experiencing the attributes of specialist food production regions are the primary motivating factor for travel" [47] (p. 308). A more comprehensive definition, and the one used in this research, includes food tourists with primary or secondary motivation. This distinguishes food tourism from the more generic hospitality sector, but still captures food tourism activity by visitors who make the decision to visit specific food tourism sites once in the location [42].

Multiple tourism researchers argue that rural food tourism development can benefit food producers, rural communities and the environment. Food tourism can contribute to economic regeneration that subsequently sustains local food systems in rural and peripheral destinations [42,48,49]. Agritourism creates a mutually reinforcing development process since food is produced for tourists and tourists are a market for food production [41] which encourages the continuation of local agricultural practices and products, and the preservation of agricultural landscapes [40,42]. For example, Sharples' (2003) study of the Chatsworth Farm shop found that rural food tourism renewed demand for local products, which kept farms alive [50]. Like agritourism for other types of farmers, wine tourism also offers economic benefits $[37,42,51]$. The provision of value-added services and experiences diversify agricultural production, especially for small producers who profit from direct to consumer sales and use tourism to create brand and product loyalty [52-54] can potentially lead to longer-term changes to consumption patterns [55]. Johnson et al. (2016) re-conceptualize agritourism tourism as a "place-based cultural activity that can raise awareness, teach, and produce progressive social change" [56] (p. 8) in their research on the Blue Ridge Women in Agriculture High Country Farm Tour, demonstrating that food tourism can also be an experiential opportunity for tourists to restore the deep caring for community and place required for global sustainability [57-59].

\subsection{Food Sovereignty in Rural Food Tourism}

Food sovereignty prioritizes the basic right to food for all, diverse local food systems, local decision making, fair value for food providers and environmentally sustainable practices. Rural food tourism that embodies these kinds of values is likely to have positive social, cultural, economic and environmental effects, yet rural food tourism and food sovereignty are seldom explicitly linked in the academic literature. The researcher is not aware of any scholarly examples of food sovereignty being considered within a tourism context in the Global North, though Santafe-Troncoso and Loring's (2021) very recently published Indigenous food sovereignty and tourism: the Chakra Route in the Amazon region of Ecuador is an excellent example of food sovereignty being brought into food tourism discourse in the Global South [60].

As seen in the description of the benefits given earlier, researchers in the Global North argue that rural food tourism can reorient agricultural production to domestic consumption, contribute to safeguarding adequate incomes for food producers and promote environmental sustainability which are the qualities for transitions to food sovereignty described by Wiebe, Nettie and Wipf (2011), but the connections are not directly established or examined. There is also limited research regarding how rural tourism stakeholders themselves conceptualize concepts related to sustainability [61] and by extension, food sovereignty. Food sovereignty aspirations need to incorporate inclusive, equitable and environmentally sustainable rural economies [8]. How might rural food tourism contribute to inclusive, equitable and environmentally sustainable rural economies and other food sovereignty priorities? This research explores how rural food tourism actors understand and mobilize the concept of food sovereignty to support rural food tourism's potential 
positive contributions to food sovereignty transitions in the context of British Columbia' South Okanagan Valley.

\subsection{Background on the South Okanagan}

The South Okanagan (SO) is the southern portion of the approximately 260 kilometre long and 130 kilometre wide Okanagan Valley located in the southern interior of British Columbia (BC), Canada's most western province, [62]. The region is 10,411.68 square kilometres [63] and borders the Washington State county of the Okonogan (American spelling) in the United States to the south, the Thompson-Nicola and Central Okanagan to the north, the Fraser Valley to the west, and the Kootenay Boundary to the east.

The region has been home to the Sylix/Okanagan people for thousands of years and is on unceded Syilx Okanagan territory [64]. The first Europeans to travel through the Okanagan were fur traders in the early part of the 19th century. European settlement began with a Catholic mission in the central Okanagan Valley in 1859. Gold miners followed in the mid-late 1800s [65,66]. Most towns in the SO were incorporated between 1902 and 1946. Travelling north to south the region begins with the district of Summerland (pop. 11, 615), followed by the city of Penticton (pop. 33, 761), and then the towns of Oliver (pop. 4928) and Osoyoos (pop. 5085). The SO also includes five rural electoral areas and the Osoyoos (pop. 762) and Penticton Indian (pop. 1783) Reserves [67].

The region has a continental climate, with a growing season marked by long days because of the latitude and low rainfall because of the Coastal Mountain Range. Temperatures range from lows of $-20^{\circ} \mathrm{C}\left(-4{ }^{\circ} \mathrm{F}\right)$ in the winter to highs of $+40^{\circ} \mathrm{C}\left(104^{\circ} \mathrm{F}\right)$ in the summer. Low levels of humidity keep pest and disease pressure low, but make irrigation essential. The series of lakes that runs through most parts of the Okanagan Valley provides some natural moderation of the climate extremes, but frosts in spring and fall and extreme winter cold are still agricultural risks [68]. The most southern portions of the Okanagan Valley are semi-arid desert and not moderated by the large Lake Okanagan [66]. There are serious concerns about the impact of climate change given the region's arid climate [69].

The South Okanagan has a long history of supporting food production. The Sylix people practiced a unique sustainable harvesting method which can be described as permaculturing because of the dry climate [70]. The first European agriculture consisted of cattle ranching and grain, which suited the open, arid landscape $[65,66]$. In the early 20th century, there were improvements to transportation with rail and steamboats, and the provincial government's South Okanagan Lands Project installed and operated gravity-fed irrigation water. As a result, the landscape transformed from the brown of grazing land and hay fields to green, pastoral orchards [65,66]. As of the 2016 Census, there were 1292 farms, down from 1506 in 2011. Agriculture, forestry, fishing and hunting represent 7.57\% of the RDOS workforce [71]. Of the 1292 farms, 912 were fruit and tree nut farms, of which 414 farms reported growing grapes [72].

The first grapes in the Okanagan were planted in mid 19th century by Father Pandosy, a Catholic missionary, and there were some other early efforts at grape growing and wine making, but the wine industry remained relatively small until the 1960s $[65,66]$. The modern $\mathrm{BC}$ wine industry followed the signing of the North American Free Trade Agreement (NAFTA) in January 1989. NAFTA's terms made a wider range of wines available to Canadian consumers at lower prices, which encouraged domestic wineries to focus on producing quality vinifera grapes and wine. Up until that time, protections afforded to the industry made innovation and quality improvements an unnecessary expense. Changing market demand and government policy such as the Grape Wine Adjustment Assistance Program (GWAPP) encouraged domestic wineries to focus on producing quality vinifera (traditional European grape varieties) and wine and the number of wineries began to significantly increase $[65,66]$.

By 2015, there were approximately 929 grape growers in BC, with a combined vineyard acreage of 10,260. Canada's Wine Economy-Ripe, Robust, Remarkable (2015) showed that the $\mathrm{BC}$ wine and grape industry contributed over $\$ 2.77$ billion to the provincial economy: 
$\$ 1.95$ billion in business revenue, $\$ 312$ million tax revenues and $\$ 512$ million wages. This represented an increase of almost $\$ 760$ million since 2011. The average bottle of wine made in BC produces $\$ 33.84$ of business revenue, $\$ 5.42$ of tax revenue and $\$ 8.91$ of wages [73].

There are now 280 wineries in 9 wine regions of BC designated with geographic indicators [74]. The largest is the Okanagan Valley with 185 wineries [68]. Because of the large size of the Okanagan Valley, the region is divided into five unofficial sub-regions to reflect the varying geographic conditions in the different parts of the valley [68]. Four of the five sub-regions and the vast majority of grapes grown in the Okanagan Valley are from the SO. Together, the South Okanagan grows $71 \%$ of the province's wine grapes [68].

In 2017, there was $\$ 18.4$ billion total tourism revenue in BC, an increase of $41.3 \%$ in a decade, and 16 million domestic and 5.6 million international visitors [75]. The BCWI estimates that more than 1 million of these visitors engage in wine tourism annually. BC wine tourism generated \$246 million in revenue in 2015 and employed about 2615 employees. It is estimated that wine industry tourism generated $\$ 206.1$ million of indirect and induced revenue and $\$ 59.3$ million of indirect and induced wages [73]. Tourism is a major contributor to the SO's regional economy [76]. Accommodation and food services represented $9.67 \%$ of the RDOS workforce in 2016 [71].

The communities of the $\mathrm{SO}$ are part of the Thompson Okanagan tourism region, one of six tourism regions in the province. Visitors to the Thompson Okanagan region represent $20 \%$ of provincial overnight visitation and 15\% of related spending in 2017. The Thompson Okanagan received 3,721,000 overnight visits in 2014 and generated over \$1.4 billion in related spending with most visits occurring during the peak summer month of July through September. Domestic overnight travellers, predominately from BC followed by Alberta, accounted for $85 \%$ of visitation and $83 \%$ of related spending. On average, tourists stayed 3.6 nights and spent $\$ 105$ per night [77].

Historically, Okanagan tourism was associated with the region's warm weather, orchards, and scenic landscape of lakes and mountains. The Okanagan's "peaches and beaches" continue to offer families an affordable vacation [78], but tourism in the SO has evolved as the wine industry has grown. The Okanagan Wine Festival Society was instrumental in developing wine tourism as were the efforts of the Osoyoos Indian Band (OIB) whose initiatives include the 'Nk'Mip Cellars' which opened in 2002 and over a thousand vineyard acres [78]. The vast majority of agritourism activity in the region consists of winery tasting room visits. Carmichel and Senese (2012) describe the current Okanagan tourism as centred around wine and the "rural aesthetic" [79] (p. 169) Schell's (2015) Gourmet International award-winning cookbook The Butcher, The Baker, The Wine and Cheese Maker illustrates how local cuisine has become a significant part of the Okanagan wine country experience in the past decade [80].

Generally, research on tourism in the Okanagan is wine centric [44,81-83]; food systems, agriculture, and critical perspectives are infrequent, though Poitras and Getz's (2006) research on the host community perspective on wine tourism in the South Okanagan identified significant risks from wine tourism development to agriculture, the community and the biophysical environment. Since then, Carmichael and Senese (2012) have applied the stage model of destination development to sustainability and competitiveness of the region's wine tourism raising issues about the industry's impact on social, cultural, and environmental resources while Kerr's (2020) unpublished Master of Public Policy thesis explored the risk of overtourism in the region [84]. With these exceptions, the researcher is not aware of follow-up on food sovereignty related themes. The researcher is only aware of one peer-reviewed article specifically related to food tourism, culinary tourism or agritourism in the Okanagan, Hjalmarson, Bunn, Cohen, Terbasket, and Gahman's (2015) discussion of migrant workers as the foundation of the regional food economy [85]. Although the wine industry has grown dramatically, these impacts have not received significant attention, nor have the potentials for capitalizing on increased consumer interest in sustainable food systems been studied. 


\section{Materials and Methods}

Theoretical considerations of food sovereignty are empirically investigated using case study methodology. Semi-structured interviews with 28 rural food tourism actors in the South Okanagan region of British Columbia were conducted in the period 2018-2019. Two additional virtual interviews were conducted in 2019 with participants working at national and international levels familiar with food tourism in the province. Participants were selected based on their leadership roles in tourism-related governmental or nongovernmental organizations, such as destination marketing or management organizations, industry associations, staff or elected representatives in local government. Several participants with more informal influence based on their public profile, educational attainments, and/or innovative tourism offering were also included. These participants tended to be younger than those involved in formal roles. Where their perspective seems unique, it is noted, but with some caution because of the small sample size. Participants were identified through internet searches of relevant organizations as well as through existing industry knowledge and referrals.

An interview guide provided a starting point, but the interviews were semi-structured, so evolved based on participants' personal responses. The research questions were framed positively because of the assumption that what we focus on becomes our reality [86]. Therefore, the findings reflect what participants thought worked. Notes were taken by the researcher during the interviews and all interviews were audio recorded. After the interviews, the researcher reviewed the notes and audio, which allowed the researcher to hear and reflect more deeply on what participants were saying. Both direct transcription and paraphrasing were used to create interview summaries. Each participant received their interview summary via email and was asked to review it for accuracy and provide any revisions as a quality control strategy. Several participants requested minor revisions to their notes, either factual corrections or a request that a specific detail be altered or removed to protect their anonymity or because that information was not publicly available. Respondent validation of the interview transcriptions/notes was an important quality control measure [87]. Interview summaries were then coded in NVivo using an iterative approach and multiple readings where data were coded into categories, and then thematic codes and sub-codes using content analysis [88].

The interviews were supplemented with other sources which included participant observation documented in field notes and photographs, journal articles, books, documents, and websites related to local, regional and provincial policies that intersect with food tourism in the South Okanagan Valley. Tourism strategy documents were considered particularly important sources because of their future orientation.

An appreciative approach was used which reflects central principles of Appreciative Inquiry (AI): the constructivist principle which refers to the ongoing social process by which we create our reality, the simultaneity principle which means that inquiry and change occur simultaneously, the poetic principle which stresses the importance of language and metaphor, the anticipatory principle where the vision of the future guides current behaviour, and the positive principle which requires social bonding to facilitate change [89]. In addition to addressing the shortcomings of problem-based research, appreciative approaches foster self-reinforcing positive relationships within the research organization or community and lead to better performance $[86,90,91]$. There are few studies in the tourism field where AI was used [92-94]; however, Nyaupane and Poudel (2012), Koster and Lemlin (2009) and Aziz et al. (2013) advocate for AI as a promising tourism research tool to understand tourism potentials in rural communities.

A significant critique of appreciative approaches is that by stressing the positive, the negative is dismissed [95]. The fear is that as a result of this positivity bias, a partial version of the truth emerges and analysis is inaccurate [96]. In view of the extensive problem-based work that has already been performed in rural tourism research, it is possible that a partial version of the truth (negative) has already emerged, and appreciative research can make contributions to the wider rural tourism and cultural sustainability fields through other 
partial truths (positive). An appreciative approach is not proposed as a panacea for all research challenges or as a replacement for other research approaches. Its value is that it offers researchers and communities "another worldview and methodology for framing and conducting tourism research ... which initiates positive changes in communities" ([93] p. 986). Although an appreciative approach limits the type of evidence gathered, this is an intentional limitation based on the belief that communities and organizations develop in the direction of what is investigated [97]. The line of questioning and the research design intend to foster the construction of positive social realities as determined by participants. This research concerns not "arriving at an eternal truth," but "developing ideas that help people to do things" [98] (p. 195).

\section{Results}

Each participant brought a perspective informed by their own experience. As a result, there were both common themes and points raised by one or only a few participants that are nevertheless very important to gaining a comprehensive understanding of how principles of food sovereignty are understood and used in rural food tourism. Efforts are made in the section below to convey the prevalence of particular qualitative findings. Sometimes this is achieved using adjectives such as few, some, many, most that describe patterns along a frequency continuum. At other times, frequency is quantified with the number in parenthesis following a statement indicating the number of respondents who expressed that idea. Direct quotes are attributed to specific participants by their numeric code. Quotes from two participants with previous experience in the South Okanagan, but who were interviewed in their capacity for a comparative case are also used to provide examples and are coded as Participant B.

The term food sovereignty was introduced by participants unprompted only twice despite being used several times in the consent form. When asked directly about how they understood food sovereignty, responses ranged from completely unfamiliar to very familiar, with the majority being in the middle of that range. Of those participants who were not familiar with the term, many could infer a general meaning by combining food with their understanding of sovereignty. For example, Participant 2 reasoned that since sovereign means controlling that which is within our boundaries, food sovereignty might refer to control over the food that is grown and sold within our boundaries. Some participants who were unfamiliar with food sovereignty thought that it might relate to Slow Food or the 100 mile diet. For two participants, food sovereignty had negative connotations that evoked the Quebec sovereignty movement and seemed to be a divisive term that would be used for political reasons to scare, manipulate, influence, and instill a sense of urgency. Several other participants saw the food sovereignty movement as a predominately fear-based reaction to globalization. For example, food sovereignty was viewed as being a reaction to the risks inherent in globalization's long food supply chains, such as distant events such as drought impacting the price of grain locally. There was a sense that trading relationships created vulnerability to external threats. Food sovereignty was seen as a climate change risk mitigation strategy and necessary consideration when "planning for the apocalypse" (Participant 4). Food sovereignty was not considered a common concern for tourism businesses. While tourism businesses may be "wanting to do the right thing" and may be interested in local food and supporting local business, they were not thought to tie initiatives such as sourcing locally back to food sovereignty (Participant 25).

A minority of participants were well acquainted with the term through their work and personal lives. These participants generally understood food sovereignty as self-selected, self-sustaining food systems. These participants thought that food sovereignty could be local, regional, provincial or national in scale. At the regional level, the SO region was not considered food sovereign because of the region's reliance on imports and a lack processing capacity, particularly for processing meat. Food sovereignty included cultural aspects not fully captured by the sub-concepts of food security which referred to having enough food, or food self-reliance which referred to sufficient internal food production. Poverty, 
organics, countering corporate power, protecting and enhancing practices such as foraging traditional plants, seed saving, supporting local small producers, sourcing all food within Canada, were mentioned in connection to food sovereignty. The Penticton Indian Band (PIB) was described as having a food sovereignty approach on their lands. There were other nuanced reflections about how food sovereignty could be understood and applied such as whether it was possible to have sovereignty over something that has been appropriated.

\subsection{Local Food}

Eating "local" was mentioned in every interview. In fact, "local" was the 4th most common word behind food, tourism, and wine. Overall, participants thought that residents of the SO increasingly appreciated the "value in getting local food especially if it is grown sustainably" (Participant 6). Local food was valued because it is better for the environment, has a higher nutritional value, is fresher, supports the local economy and connects consumers with producers. In terms of wine consumption, there is a well-developed culture of local consumption; however, the higher cost of BC wine was observed. Irrespective of desire to buy local, local wine and food culture participation is expensive in the Okanagan and participants thought that the SO wine, restaurants, and agritourism events were not at a price range that was affordable for many locals.

Local distribution of both wine and food was predominately to restaurants and through busy farmers' markets, particularly Penticton's Farmers' Market. These settings were "where people who want the food and people who've got the food meet" (Participant 10). There was also one mention of community supported agriculture (CSA) in reference to Localmotive a small local produce distribution company (Participant 5). Distributors such as Sysco were described as becoming more sensitive to local food supplies evidenced by their local test kitchen, local distribution, and respect for seasonal supply issues. However, participants described a disconnect between what is grown in region and what is available to purchase in grocery stores or eat in typical restaurants. Most of the produce available at local grocery stores was transported into the region. This was attributed to contracts, supply chain, and other variables that drive the product mix. Export was seen as important for certain products. For example, cherry production is export focused, particularly to Asian markets. This international renown was seen as critical to creating and maintaining Canada's food identity.

\subsection{Local Livelihoods}

Communities in the South Okanagan were described as being mutually invested in each other's success because the communities are so interconnected and a significant percentage of the population is involved in agriculture, tourism, wine, and/or culinary. In agricultural communities such as those of the SO, "food really drives the character and flavour of a community" (Participant 2) so sustaining food, sustains community and tourism helps build and sustains a sense of community identity. Tourism was described as "a renewable resource as long as you don't over tourist it" (Participant 1). In particular, wine tourism was seen as creating demand for other agricultural products. Food and beverage were central to branding the region for visitors and potential residents. Food tourism creates brand ambassadors for wine and food and the destination, which can feed future success. Participant 21 gave a personal example of running an orchard that would lose money if its fruit was sold wholesale, but could profit with direct sales to tourists, locals, and restaurants. Direct sales were seen as a win-win approach since the local farmer makes a better margin and the consumer gets fresher produce at a better price. Adding tourism experiences creates additional opportunities for farmers that are trying to diversify for alternate revenue streams.

The agricultural lifestyle was considered an important aspect of why other industries such as manufacturing and technology establish themselves in the South Okanagan. Other newcomers to the South Okanagan create their own jobs through entrepreneurial activity often centred on food and wine. The South Okanagan's identity as a wine and food region 
attracted retirees with diverse backgrounds and interest in community involvement. It also attracted younger people. The youngest BC participant, Participant 18, felt that there were more younger farmers and entrepreneurs in food-related businesses moving to the Okanagan. Participant 16, the second youngest participant, felt that "young working people with families" were the ones setting a positive entrepreneurial tone. This demographic vitality was considered essential to sustaining rural places.

The most economically viable agri-businesses are wine and other alcoholic beverage producers who utilize tourism as the most lucrative sales channel. Wine was described as having margin advantages, especially when scaled up, whereas other agriculture was high cost and low margin. Wine tourism is the tourism development activity with the most significant spin off and multiplier in terms of economic development in other tangential sectors such as accommodation. Wine tourism was established with expanding the shoulder season as a key objective. For example, the Okanagan Wine Festival was established because tourism used to stop at Labour day and later the Spring Wine Festival was added for similar reasons. Wine tourism successfully extended the season with several participants noticing that September may have fewer visitors but they spend more.

Wine tourism has been transformative for the South Okanagan but "whether that transformation filters into the rest of the community who aren't so privileged is a big question" (Participant 7). Multiple participants thought that it is important that development which was intended to serve the community continues to serve the community, so the tone of economic development should be about serving locals not catering to wineries. Food tourism operators need to attract and retain staff, which requires an adequate supply of affordable accommodation and fair wages. Animosity develops when service people cannot afford a reasonable lifestyle as is the case in Napa Valley, California where there are "full-time tasting room staff living in ghetto apartments in the back suburbs of Napa" (Participant B22). A viable rural community depends on being able to give people a sense of hopefulness about the future which becomes difficult when people cannot afford to buy a home in the community where they grew up. Participant B19 explained that in the early days of the BC wine industry's development, "it was still relatively affordable for people who were born and raised there and wanted to create a life for themselves and buy a home" but this is no longer the case.

\subsection{Local Environments}

Agriculture's potential for negative effects on the environment were acknowledged by some participants. For example, there were concerns that vineyards and orchards have contributed to degradation of natural habitat and that too much fertilizer and spraying has produced negative consequences such as run off to lakes. Water usage was another area of concern. Participants thought that locals have become more aware and concerned about agricultural issues related to environmental impacts and health. Although the South Okanagan climate allows growing without as much intervention, organic farming does not dominate farming in the region. There was general agreement about the need for agricultural practices that respect the land, but participants were not unanimous regarding this necessarily being officially organic because some thought that in certain cases pesticides may be necessary and may produce more nutritious food and not have negative residue.

South Okanagan participants described a cycle where food tourism incentivized the region to protect food sources and protect the environment and agricultural landscape where these foods are grown. Food tourism was seen as an incentive for the SO to protect agricultural assets, which is important because it makes the $\mathrm{SO}$ a desirable place to live and to visit. Sustaining local agriculture depended on farmers being able to make a livelihood, so the opportunity to use agricultural land in food and wine tourism provided a means for farmers to maintain the environmental, social, and cultural qualities of local agriculture. For example, cideries ensure orchards stay in place and Farmers' Markets protect food sources and the infrastructure and relationships for local distribution. Even when the growth of the wine industry meant transitioning from orchards to vineyards, the agricultural identity 
and aesthetic was protected. The objectives of agricultural land conservation were met since the soil could be converted to other crop uses in the future if necessary.

The Okanagan wine industry was seen as having been a leader in some aspects of sustainability, with several examples of wineries such as Monte Creek, Burrowing Owl, and Summerhill making sustainability central to their brand. Wineries looking for less impact can press growers to use more environmentally sustainable practices. It was considered very significant when Mission Hill Winery announced that they were transitioning all vineyards to organic, since Mission Hill is a large, premium, flagship winery. This shows how "someone in a position of influence and leadership is making everyone turn their head" (Participant 25). It allows other wineries to follow with less risk since they can assume Mission Hill has performed viticulture and market research. Sustainability was seen as a key part the South Okanagan's appeal as a wine region that attracts visitors who want to be part of a sustainable experience.

Many participants felt that wine has helped people value their local landscape. The wine industry also celebrates and creates a market for other local food products and culinary offerings. However, agriculture was seen as being vulnerable to market-driven monoculture. Maintaining agricultural diversity was a priority expressed frequently in the Okanagan (7). Participants described some community ambivalence towards wineries because that agricultural land could be producing food. A10 referenced a t-shirt slogan that read "we're going to be drunk and hungry in our future if we don't stop ripping orchards out and putting grapevines in" which captured the sentiment.

A participant with experience that spanned the entire growth of farm wineries in BC described now being overwhelmed by the number of new wineries. Participant B12 went on to say:

I used to know everybody, anybody in the business, but not anymore and I was just kind of sad to see all the other fruit gone because everything is in the grape vines now and I guess anybody who is somebody has to have a winery ... No more apricot orchards ... it's all grapes.

The general sentiment was that South Okanagan needs to be very careful not to turn into a monoculture for a variety of reasons. One reason participants felt it was important to maintain agricultural diversity was environmental. Not being a monoculture was considered better for the environment because that diversity provides habitat, wildlife corridors, symbiotic pests between crops and therefore less need for pesticide. Monocultures were seen as more vulnerable to disease such as the spotted wing drosophila. Participants felt that diversity was a risk mitigation strategy akin to "not putting all our eggs in one basket" (Participant 3). Monoculture erodes local food supply, so was a threat to those valued aspects of local food culture such as actually growing food. Monoculture also threatened food tourism's sustainability. It was argued that visitors want that agricultural diversity. "Nobody wants to come and just see vineyards" (Participant 15). The landscape is attractive to visitors and locals when it is mixed.

There was increasing awareness of the seriousness of the environmental situation, especially climate change. There was a sense that there was more interest and openness to these considerations in the last 5 or so years, with a growing recognition that there is a business case for sustainable practices such as operational efficiencies, being able to demand higher price, and being able to attract consumers and staff who value sustainability. Local tourism operators were described as "hungry for a way to do that that still makes sense for their business" (Participant 25). Because as Participant 12 argued, "you can't talk about sustainability unless they actually make money."

\subsection{Transformations for Food Sovereignty?}

Participants described food tourism as contributing to changing the values and perspectives of locals and tourists in ways that moved towards a sustainable culture. Locals may take the beauty of the agricultural landscape for granted. They are reminded to appreciate their place when tourists come to enjoy their landscape, food and wine. Partici- 
pants thought that external recognition of something makes the people who are local to it appreciate it more. Tourism was described as a "give and take" between hosts and guests. Participants described tourism as an opportunity to build relationships. Food tourism facilitated mutual exchange in particular because food is universal. Sharing food and drink puts people at ease and creates comradery.

The transformative potential of food experiences to reconnect people with the natural environment and with other people was seen as a core objective of food tourism. Several participants felt there is often a disconnect in the food system between consumers and producers and between consumers and the land. Food tourism was viewed as a means to build human connections between consumers and producers and connections between consumers and the natural environment. Ultimately, participants thought that these deeper connections would transform cultural behaviour. These connections would increase caring about rural places and thereby increase sustainable behaviour such as buying local. Participant 18 described her food tourism initiative as aiming to get people to think in new ways and ultimately to "break little habits one step at a time." Direct experience could potentially shift consumer interest from quantity to quality.

Participants thought that people needed to experience something to value it. Therefore, time and sensory experiences were essential in the transformational learning experiences described. Time with the visitor allows for a much deeper connection than a customer would get just through a typical retail-type sale. Several participants had received feedback from tourists about "ah ha" moments after tourism experiences. Food is experienced with multiple senses and these "ah ha" experiences stressed sensory experience such as picking and tasting fruit, or walking barefoot in the dirt a visceral, grounding experience which Participant 20 found "makes people feel better."

There were positive examples of how tourists learned about Indigenous culture, history, and politics over the course of food and wine tours hosted by Indigenous guides. Several South Okanagan participants expressed their own desire to learn about food from local Indigenous people. Participants wanted to learn more about foraging, hunting, or how to cook things. Some participants sensed distrust which they thought was understandable. Non-Indigenous participants thought that Indigenous food knowledge keepers might think: "what are your reasons, why are you interested in this, how are you going to exploit us" (Participant 3). It was stressed that not every aspect of culture should be public and that there was a fine line between "teaching and providing an experience and exploitation." Only telling part of the story is disrespectful, but there are things that are not for sharing. Where certain things grow, plants used for medicines, and water sources must be guarded and protected. Participant 19 shared an example about information being shared online about a local spring. This distressed the community who knew from experience that it would be exploited if that knowledge was shared.

\section{Discussion}

The connections participants made between rural food tourism and local food, livelihoods and environments demonstrate that although the term food sovereignty did not resonate for most participants, the qualities of a transition to food sovereignty identified by Wiebe, Nettie and Wipf (2011) such as reorienting agriculture, food processing and consumption to the local region, supporting rural livelihoods and communities, and environmental sustainability were considered integral to rural food tourism. Participants also described the power of transformative food tourism reconnect people with food systems and with each other. However, there are important considerations that require deeper attention.

There is a need to interrogate the concept of local from cultivation, through to production, distribution and consumption $[42,99,100]$, with attention to spatially, culturally, socially, and economically determined power discrepancies. Probing how communities decide which local people count as locals is an important area for reflection since local is implicitly or explicitly determined by race, class, and gender [101]. Are colonial settlers 
local to a place where the Syilx/Okanagan people lived sustainably for thousands of years and where they still affirm that the land is theirs since there is no treaty? [77] Which locals can afford local food? The region depends on temporary foreign agricultural workers, and expected almost 4500 seasonal workers in 2020, with $80 \%$ of participants in the Seasonal Agricultural Worker Program returning annually [102]. Are their contributions and rights respected? The wine country lifestyle tends to attract people and capital from outside the region, a pattern that is well established in the South Okanagan. What are the implications to food sovereignty if agricultural land owners are predominately from outside the region? In addition, carbon emissions from air travel are oft neglected in food tourism literature [103] and were not discussed by participants. Carbon emissions from tourism should be discussed, as should the ironies of tourism being an export dependent on bringing visitors out of their own local. Finally, considering how deeply tourism has been affected by the COVID-19 pandemic and how the pandemic has drawn attention to food systems vulnerabilities, it is critical to revisit these themes in future research to understand how perspectives have evolved. Critical perspectives such as food sovereignty can highlight the interrelationships between various actors' power, values, cultural norms and motivations while appreciative research approaches keep the focus aspirational.

Participants' vision of future wine and food tourism was centred on connection to place and people and using food tourism to meet objectives which often focused on transformational food tourism experiences. Yet, social meaning making and community building aspects are mostly absent in the wine tourism literature with the exception of Quintal, Thomas, and Phau's (2015) discussion of service staff and Bruwer and Gross' (2017) inclusion of employees and locals in their seven point scale of the winescape construct $[104,105]$. It is not clear why these more purposeful or transformational aspects were evident in this research, but are not prevalent in wine tourism research. There are a variety of possibilities. For example, these particular participants had unique perspectives, these types of transformational tourism ideas are quite recent and have not yet been captured in academic work, the appreciative research design affected the type of responses and/or this research examined a broader sustainability context where questions about food culture and tourism prompted alternative impressions that would not have emerged in if studying wine tourism in isolation.

Rural food tourism's role in transformational cultural change was depicted by participants and is generally shown in the literature as part of the green economy [106]. The green economy is a neoliberal conceptualization, so market-based mechanisms such as individual consumption are considered the most effective and efficient change agents and are presented as an alternative to collective organization for policy change [101]. At a time generally characterized by political disengagement, individual consumption has become the political act [107].

Critical consumers have demanded more sustainable food and tourism practices and there have been successes where alternative consumption movements have influenced business in areas such as increased organic produce. However, the likelihood of transformational effects from food tourism is limited because of the limited duration of these experiences [108]. In addition, there are valid questions about how democratic a 'vote with your wallet' orientation to local food is, given that "individuals participate in the green economy not as equal citizens, but as consumers with unequal access to wealth and products and as producers with unequal access to capital and markets" [101] (p. 10). Power differentials and difficult trade-offs are neglected when the green economy is given as an alternative to policy reform and collective organization $[4,109]$.

Most participants focused on behavioural approaches to change, framed using the dominant attitude, behaviour and choice paradigm. According to this paradigm, "people could and would act differently if only they knew what damage they were doing" [110] (p. 4) but many participants also recognized that individual choices are not made in isolation but within a culture with its attendant norms and values and status signifiers. These participants were aware of aspects of rural community sustainability such as equity and their ideas sometimes reflected 
the principles of food sovereignty despite the term not being a cultural fit. Food sovereignty depends both on individual actions, such as participating in agritourism experiences and buying local food, and on the ability to mobilize individual action into collective enterprises that alter the basic structures of the system, thereby fostering more individual actions [111-113].

\section{Conclusions}

Food sovereignty is rarely considered in the academic literature within a rural tourism context despite rural food tourism having the potential to contribute to transitions to food sovereignty as described by Wiebe, Nettie and Wipf (2011). This research brought the perspective of rural food tourism actors to the discussion of food sovereignty at the intersection of food and mobilities in the South Okanagan wine region of British Columbia. Using an appreciative approach created space for participants to explore tourism's role in advancing tenets of food sovereignty such as the basic right to food for all, diverse local food systems, local decision making, fair value for food providers and environmentally sustainable practices. The need to critically probe the concepts of local and the green economy with consideration to spatially, culturally, socially, and economically determined power discrepancies was identified, as was the need to consider transformation at the policy level.

The pandemic has been a crisis for the tourism sector as travel restrictions have severely limited mobility, with the United Nations World Tourism Organization (UNWTO) estimating that 2020 would see a $58-78 \%$ decrease in global tourism [114], but this crisis has also created possibilities for deep reflection about how tourism can more sustainably support social, cultural and economic development. This opportunity for transformation is noted by scholars and tourism practitioners [114-117]. For example, the South Okanagan's regional destination management association, the Thompson Okanagan Tourism Association (TOTA), hosted its annual summit in November 2020, with the aim of virtually bringing together the tourism community "to learn, strategize, collaborate, and move forward better than before" [118]. Anna Pollock of Conscious Travel concluded her keynote speech at the summit with an analogy that reflects both a new focus for relational tourism that supports recovery and the close parallels between thriving rural tourism destinations and thriving food systems: "Community is to regenerative tourism what soil is to regenerative agriculture."

Clearly, the time is ripe for further academic, community and policy dialogue about tourism's purpose in transformational reorientations towards flourishing through local food, livelihoods and healthy environments for hosts and guests in rural agricultural regions. The research presented in this paper was conducted before the COVID-19 pandemic.

Future research can explore whether COVID-19 has transformed rural tourism stakeholders understanding of the interrelationships between tourism and food sovereignty. A better understanding of these interconnections will support proactively addressing the negative effects of tourism development, and fully foster the potential positive contributions that rural food tourism might make to food sovereignty transitions.

Funding: This paper is based on part of my doctoral research: Robinson, D. M. (2020). Cultural Sustainability and Rural Food Tourism in Two Canadian Wine Regions [Unpublished Doctoral Dissertation]. University of Guelph. which was generously supported by The Rural Policy Learning Commons (RPLC) with a Research and Exchanges Service Rural Policy Research Grant.

Institutional Review Board Statement: The study was conducted according to the guidelines of the Declaration of Helsinki, and approved by the Institutional Review Board (or Ethics Committee) of the University of Guelph (REB 18-10-018 October 30, 2018).

Informed Consent Statement: Informed consent was obtained from all subjects involved in the study.

Data Availability Statement: There is no data available for what is reported. 
Acknowledgments: With thanks to the guidance of my PhD Advisory Committee at the University of Guelph, Wayne Caldwell, Al Lauzon and Sheri Longboat and to Kathleen Kevany at Dalhousie University for sharing her knowledge of food sovereignty.

Conflicts of Interest: The researcher has personal experience in the BC wine industry; therefore, she is not objective in the sense of personal distance from the case or participants in this study; however, quality control strategies were used throughout the research process to ensure the research accurately captured the case details and multiple sources and methods were used to support validity. The funders had no role in the design of the study; in the collection, analyses, or interpretation of data; in the writing of the manuscript, or in the decision to publish the results.

\section{References}

1. Wiebe, N.; Wipf, K. Nuturing Food Sovereignty in Canada. In Food Sovereignty in Canada: Creating Just and Sustainable Food Systems; Wittman, N.H., Desmarais, A.A., Wiebe, Eds.; Fernwood Pub: Halifax/Winnipeg, MB, Canada, 2011; pp. 1-19.

2. Wittman, H. From protest to policy: The challenges of institutionalizing food sovereignty. Can. Food Stud. Rev. Can. Études Aliment. 2015, 2, 174-182. [CrossRef]

3. Fairbairn, M. Framing transformation: The counter-hegemonic potential of food sovereignty in the US context. Agric. Hum. Values 2011, 29, 217-230. [CrossRef]

4. Moragues-Faus, A.; Marsden, T. The political ecology of food: Carving 'spaces of possibility' in a new research agenda. J. Rural Stud. 2017, 55, 275-288. [CrossRef]

5. Altieri, M.A.; I Nicholls, C. Scaling up agroecological approaches for food sovereignty in latin America. Development 2008, 51, 472-480. [CrossRef]

6. Francis, C.; Lieblein, G.; Gliessman, S.; Breland, T.A.; Creamer, N.; Harwood, R.; Salomonsson, L.; Helenius, J.; Rickerl, D.; Salvador, R.; et al. Agroecology: The ecology of food systems. J. Sustain. Agric. 2003, 22, 99-118. [CrossRef]

7. Chaifetz, A.; Jagger, P. 40 Years of dialogue on food sovereignty: A review and a look ahead. Glob. Food Secur. 2014, 3, 85-91. [CrossRef]

8. Edelman, M.; Weis, T.; Baviskar, A.; Borras, S.M.; Holt-Giménez, E.; Kandiyoti, D.; Wolford, W. Introduction: Critical perspectives on food sovereignty. J. Peasant. Stud. 2014, 41, 911-931. [CrossRef]

9. Clapp, J. Food security and food sovereignty: Getting past the binary. Dialogues Hum. Geogr. 2014, 4, 206-211. [CrossRef]

10. George, E.W. World Heritage, Tourism Destination and Agricultural Heritage Landscape: The Case of Grand Pré, Nova Scotia, Canada. J. Resour. Ecol. 2013, 4, 275-284. [CrossRef]

11. Kevany, K.M. Opportunities and challenges with plant-rich strategies. In Plant-Based Diets for Succulence and Sustainability; Routledge: Boca Raton, FL, USA, 2019; pp. 1-11.

12. Levkoe, C. Food sovereignty in Canada: Creating just and sustainable food systems. J. Peasant. Stud. 2013, 40, 293-297. [CrossRef]

13. Connell, D.J.; Bryant, C.R.; Caldwell, W.J.; Churchyard, A.; Cameron, G.; Johnston, T.; Marois, C. Food Sovereignty and Agricultural Land Use Planning: The Need to Integrate Public Priorities across Jurisdictions. J. Agric. Food Syst. Community Dev. 2013, 3, 117-124. [CrossRef]

14. Mariola, M.J. Losing ground: Farmland preservation, economic utilitarianism, and the erosion of the agrarian ideal. Agric. Hum. Values 2005, 22, 209-223. [CrossRef]

15. Troughton, M. Fordism rampant: The model and reality, as applied to production, processing and distribution in the Noth American agro-food system. In Rural Change and Sustainability: Agriculture, the Environment and Communities; Essex, S., Gilg, A.W., Yarwood, R.B., Smithers, J., Wilson, B., Eds.; CABI: Wallingford, UK, 2005; pp. 13-27.

16. Food Secure Canada. Discussion Paper: Food Sovereignty in Rural and Remote Communities. Food Secure Canada. 2015, p. 14. Available online: https://foodsecurecanada.org/sites/foodsecurecanada.org/files/DP2_Food_Sovereignty_in_Rural_ and_Remote_Communities.pdf (accessed on 5 February 2021).

17. Woods, M. Engaging the global countryside: Globalization, hybridity and the reconstitution of rural place. Prog. Hum. Geogr. 2007, 31, 485-507. [CrossRef]

18. Scrinis, G. Reformulation, fortification and functionalization: Big Food corporations' nutritional engineering and marketing strategies. J. Peasant. Stud. 2015, 43, 17-37. [CrossRef]

19. Qualman, D. Advancing agriculture by destroying farms. In The State of Agriculture in Canada. Food Sovereignty in Canada: Creating Just and Sustainable Food Systems; Wittman, N.H., Desmarais, A.A., Wiebe, Eds.; Fernwood Pub: Halifax/Winnipeg, MB, Canada, 2011; pp. 20-42.

20. Statistics Canada. 2016 Census of Agriculture. Stat. Can. 2017, 1-13. Available online: https://www.statcan.gc.ca/eng/ca2016 (accessed on 5 February 2021).

21. National Farmers Union. NFU Brief on A Food Policy for Canada; NFU: Saskatoon, SK, Canada, 2017.

22. Lauzon, A. Food Insecurity and the Rural Elderly | Al Lauzon I Pulse I LinkedIn 2017. Available online: https: / / www.linkedin. com/pulse/food-insecurity-rural-elderly-al-lauzon/ (accessed on 10 April 2018).

23. Reid, D.G. Tourism, Globalization and Development: Responsible Tourism Planning; Pluto Press: London, UK, 2003. 
24. George, E.W.; Mair, H.; Reid, D.G. Rural Tourism Development: Localism and Cultural Change; Channel View Publications: Clevedon/Buffalo, UK, 2009.

25. Carneiro, M.J.; Lima, J.; Silva, A.L. Landscape and the rural tourism experience: Identifying key elements, addressing potential, and implications for the future. J. Sustain. Tour. 2015, 23, 1217-1235. [CrossRef]

26. Jepson, D.; Sharpley, R. More than sense of place? Exploring the emotional dimension of rural tourism experiences. J. Sustain. Tour. 2014, 23, 1157-1178. [CrossRef]

27. Macdonald, R.; Jolliffe, L. Cultural rural tourism. Ann. Tour. Res. 2003, 30, 307-322. [CrossRef]

28. Lane, B.; Kastenholz, E. Rural tourism: The evolution of practice and research approaches-towards a new generation concept? J. Sustain. Tour. 2015, 23, 1133-1156. [CrossRef]

29. Brooker, E.; Joppe, M. Entrepreneurial Approaches to Rural Tourism in the Netherlands: Distinct Differences. Tour. Plan. Dev. 2014, 11, 343-353. [CrossRef]

30. Sharpley, R. Tourism Development and the Environment: Beyond Sustainability? Earthscan: Abingdon, UK, 2009.

31. Long, J.; Vogelaar, A.; Hale, B.W. Toward sustainable educational travel. J. Sustain. Tour. 2014, 22, 421-439. [CrossRef]

32. Hillery, M.; Nancarrow, B.; Griffin, G.; Syme, G. Tourist perception of environmental impact. Ann. Tour. Res. 2001, 28, 853-867. [CrossRef]

33. Butler, R.; Hinch, T. Tourism and Indigenous Peoples: Issues and implications; Butterworth-Heinemann: Oxford, UK, 2007.

34. Kozak, N.; Kozak, M. Sustainability of Tourism Cultural and Environmental Perspectives; Cambridge Scholars Publishing: Newcastle upon Tyne, UK, 2011.

35. Streimikiene, Y.; Bilan, D. Review of rural tourism development theories. Transform. Bus. Econ. 2015, 14, 21-34.

36. Ellis, A.; Park, E.; Kim, S.; Yeoman, I. What is food tourism? Tour. Manag. 2018, 68, 250-263. [CrossRef]

37. Croce, E.; Perri, G. Food and Wine Tourism: Integrating Food, Travel and Terroir; CABI: Wallingford, UK, 2017.

38. Colton, J.W.; Bissix, G. Developing agritourism in Nova Scotia: Issues and challenges. J. Sustain. Agric. 2005, 27, 91-112. [CrossRef]

39. Chase, L.; Stewart, M.; Schilling, B.; Smith, B.; Walk, M. Agritourism: Toward a Conceptual Framework for Industry Analysis. J. Agric. Food Syst. Community Dev. 2018, 8, 1-7. [CrossRef]

40. Vaugeois, N.; Bence, S.; Romanova, A. Farm Diversification Through Agri-tourism: A Manual to Guide Development; British Columbia Ministry of Agriculture: Abbotsford, BC, USA, 2017. Available online: https://www2.gov.bc.ca/assets/gov/ farming-natural-resources-and-industry/agriculture-and-seafood/farm-management/farm-business-management/businessplanning-guides/agritourism_guide_2017.pdf (accessed on 5 February 2021).

41. Sonnino, R. For a 'piece of bread'? Interpreting sustainable development through agritourism in southern Tuscany. Sociol. Rural. 2004, 44, 285-300. [CrossRef]

42. Everett, S. Food and Drink Tourism: Principles and Practice; SAGE: Los Angeles, CA, USA, 2016.

43. Bell, D. Destination drinking: Toward a research agenda on alcotourism. Drugs Educ. Prev. Policy 2008, 15, 291-304. [CrossRef]

44. Senese, D.; Randelli, F.; Hull, J.S. The role of terroir in tourism led amenity migration: Contrasting effects in Tuscany and the Okanagan Valley of British Columbia. In Proceedings of the 11th International Terroir Congress, McMinnville, OR, USA, 10-14 July 2016; pp. 116-123.

45. Yeoman, I.; McMahon-Beatte, U. The future of food tourism. J. Tour. Futur. 2016, 2, 95-98. [CrossRef]

46. Bennett, L.; Kim, R.; Miller, C. Farms \& Farmers' Markets. In Have Fork Will Travel; World Food Travel Association: Portland, OR, USA, 2014; pp. 251-262.

47. Hall, M.C.; Mitchell, R. Wine and food tourism. In Special Interest Tourism; Douglas, R., Derrett, N., Eds.; John Wiley and Sons: Hoboken, NJ, USA, 2001.

48. Rachão, S.; Breda, Z.; Fernandes, C.; Joukes, D.V. Food tourism and regional development: A systematic literature review. Eur. J. Tour. Res. 2019, 21, 33-49.

49. Lee, K.H.; Scott, N.; Packer, J. Where does food fit in tourism? Tour. Recreat. Res. 2014, 39, 269-274. [CrossRef]

50. Sharples, L. Food tourism in the peak district national park, England. In Food Tourism Around the World; Hall, B., Sharples, C.M., Mitchell, L., Macionis, R., Cambourne, N., Eds.; Routledge: Boca Raton, FL, USA, 2003; pp. 206-227.

51. Baldwin, B.; Mellows, M.B.A.S. Okanagan Wine Tourism Industry Economic Impact Report; Okanagan Wine Festivals Society, the BC Wine Institute and the Okanagan College School of Business: Kelowna, BC, Canada, 2013.

52. Getz, D.; Brown, G. Benchmarking wine tourism development. Int. J. Wine Mark. 2006, 18, 78-97. [CrossRef]

53. Macionis, N. Wine and Food Tourism in the Australian Capital Territory: Exploring the Links. Int. J. Wine Mark. 1998, 10, 5-22. [CrossRef]

54. Sidali, K.L.; Kastenholz, E.; Bianchi, R. Food tourism, niche markets and products in rural tourism: Combining the intimacy model and the experience economy as a rural development strategy. J. Sustain. Tour. 2015, 23, 1179-1197. [CrossRef]

55. Kim, S.; Lee, S.K.; Lee, D.; Jeong, J.; Moon, J. The effect of agritourism experience on consumers' future food purchase patterns. Tour. Manag. 2019, 70, 144-152. [CrossRef]

56. Johnson, N.; Schnakenberg, L.; Perdue, G. Placing local food systems: Farm tours as place-based sustainability education. J. Sustain. Educ. 2016, 11, 1-29.

57. Casey, E.S. Between Geography and Philosophy: What Does It Mean to Be in the Place-World? Ann. Assoc. Am. Geogr. 2001, 91, 683-693. [CrossRef] 
58. DeLind, L.B. Of Bodies, Place, and Culture: Re-Situating Local Food. J. Agric. Environ. Ethic. 2006, 19, 121-146. [CrossRef]

59. Horlings, L.G. Values in place; A value-oriented approach toward sustainable place-shaping. Reg. Stud. Reg. Sci. 2015, 2, 257-274. [CrossRef]

60. Santafe-Troncoso, V.; Loring, P.A. Indigenous food sovereignty and tourism: The Chakra Route in the Amazon region of Ecuador. J. Sustain. Tour. 2021, 29, 391-410. [CrossRef]

61. Calza, F.; Go, F.M.; Parmentola, A.; Trunfio, M. European rural entrepreneur and tourism-based diversification: Does national culture matter? Int. J. Tour. Res. 2018, 20, 671-683. [CrossRef]

62. Buschert, K.; Mooken, M.; Pesme, J.-O.; Sugden, R.; Valania, M. BC Wine Territory Identity; UBC/Kedge Wine Industry Collaboration. 2018. Available online: https://open.library.ubc.ca/cIRcle/collections/facultyresearchandpublications/52383/items/1. 0385569 (accessed on 5 February 2021).

63. Statistics Canada. Census Profile, 2016 Census-British Columbia [Province] and Canada [Country] 2016. Available online: https:/ / www12.statcan.gc.ca/census-recensement/2016/dp-pd/prof/details/page.cfm?Lang=E\&Geo1=PR\&Code1=59\& Geo2=PR\&Code2=01\&SearchText=Canada\&SearchType=Begins\&SearchPR=01\&B1=All\&type=0 (accessed on 9 November 2019).

64. ONA. Syilx/Okanagan Nation - Okanagan Nation Alliance. Available online: https://www.syilx.org/about-us/syilx-nation/ (accessed on 5 December 2019).

65. Senese, D.M.; Wilson, W.; Momer, B. The Okanagan Wine Region of British Columbia, Canada. In The Geography of Wine; Springer: Amsterdam, The Netherlands, 2012; pp. 81-91.

66. Whittall, L. Valleys of Wine: A taste of British Columbia's Wine History; Whitecap Books: Vancouver, BC, Canada, 2019.

67. Statistics Canada. Census Profile, 2016 Census Okanagan-Similkameen, Regional District [Census Division], British Columbia and British Columbia [Province] 2016. Available online: https://www12.statcan.gc.ca/census-recensement/2016/dppd/prof/details / page.cfm?Lang=E\&Geo1=CD\&Code1=5907\&Geo2=PR\&Code2=59\&Data=Count\&SearchText=OkanaganSimilkameen \&SearchType=Begins\&SearchPR=01\&B1=All\&GeoLevel=PR\&GeoCode=5907\&TABID=1 (accessed on 5 February 2021).

68. BC Wine Institute. BCWI Media Kit; BCWI: Kelowna, BC, Canada, 2017.

69. Belliveau, S.; Bradshaw, B.; Smit, B.; Reid, S.; Ramsey, D.; Tarleton, M.; Sawyer, B. Farm-level adaptation to multiple risks: Climate change and other concerns. Occas. Pap. 2006, 27.

70. Armstrong, J. Interviewed by David E. Hall: Native Perspectives on Sustainability Project. Nativ. Perspect. Sustain. $2007,1-13$.

71. Statistics Canada. Okanagan-Similkameen, Regional district [Census division], British Columbia and British Columbia Province. Census Profile, 2016 Census; SC: Ottawa, ON, Canada, 2017.

72. Statistics Canada. Table 32-10-0447-01 Farms Reporting Selling Agricultural Products Directly to Consumers in the Year Prior to the Census 2016. Available online: https://www150.statcan.gc.ca/t1/tbl1/en/tv.action?pid=3210044701 (accessed on 5 February 2021).

73. Rimerman, A.F.; Eyler, R. The Economic Impact of the Wine and Grape Industry in Canada 2015: Canada's Wine Economy-Ripe, Robust, Remarkable. 2015. Available online: https://www.winegrowerscanada.ca/wp-content/uploads/2020/04/CanadaEconomic-Impact-Report-2015.pdf (accessed on 5 February 2021).

74. BC Wine Institute. Discover BC Wine Country. Available online: https://winebc.com/discover-bc-wine-country/ (accessed on 5 February 2021).

75. Destination British Columbia. Value of Tourism: Trends 2007-2017; DBC: Vancouver, BC, Canada, 2018.

76. Regional District Okanagan-Similkameen. South Okanagan Regional Growth Strategy; RDOS: Penticton, BC, Canada, 2017.

77. Destination British Columbia. Regional Tourism Profile Thompson Okanagan; DBC: Vancouver, BC, Canada, 2017.

78. Poitras, L.; Getz, D. Sustainable wine tourism: The host community perspective. J. Sustain. Tour. 2006, 14, 425-448. [CrossRef]

79. Carmichael, B.A.; Senese, D.M. Competitiveness and Sustainability in Wine Tourism Regions: The Application of a Stage Model of Destination Development to Two Canadian Wine Regions. In The Geography of Wine; Springer: Dordrecht, The Netherlands, 2012; pp. 159-178.

80. Schell, J. The Butcher, The Baker, The Wine and Cheese Maker; TouchWood Editions: Victoria, BC, Canada, 2015.

81. Conlin, M.; Rice, A. The Future of Wine Tourism in the Okanagan Valley: A Delphi Method Survey. In Wine Tourism Destination Management and Marketing; Springer International Publishing: Berlin/Heidelberg, Germany, 2019; pp. $423-444$.

82. Hira, A.; Bwenge, A. The Wine Industry in British Columbia: A Closed Wine but Ready for Harvest. In What Makes Clusters Competitive?: Cases from the Global Wine Industry; Simon Fraser University: Burnaby, BC, Canada, 2013; pp. 85-126. Available online: https://www.researchgate.net/publication/228603011_The_Wine_Industry_in_British_Columbia_A_Closed_Wine_ But_Ready_for_Harvest (accessed on 5 February 2021).

83. Senese, D. Amenity Resources and Rural Change in the Okanagan Valley of British Columbia. In The Rural-Urban Fringe in Canada: Conflict \& Controversy; Rural Development Institute: Brandon, MB, Canada, 2010; pp. 158-175.

84. Kerr, L. Sour grapes: Mitigating the Risk of Overtourism in British Columbia's Eno-Tourism. Master's Thesis, Simon Fraser University, Burnaby, BC, Canada, 2020.

85. Hjalmarson, E.; Bunn, R.; Cohen, A.; Terbasket, E.; Gahman, L.L. Race, food, and borders: Situating migrant struggle in the Okanagan Valley, British Columbia. J. Agric. Food Syst. Community Dev. 2015, 5, 77-82.

86. Hammond, S. The Thin Book of Appreciative Inquiry; Thin Book Pub Co.: Bend, OR, USA, 2013. 
87. Torrance, H. Triangulation, Respondent Validation, and Democratic Participation in Mixed Methods Research. J. Mix. Methods Res. 2012, 6, 111-123. [CrossRef]

88. Weber, R. Basic Content Analysis; Sage: Newbury Park, CA, USA, 1990.

89. Cooperrider, D.L.; Whitney, D. Appreciative Inquiry: A Positive Revolution in Change; Barrett-Koehler Publishers: Oakland, CA, USA, 2005

90. Ludema, D.; Whitney, D.; Mohr, B.J.; Griffin, T.J. The Appreciative Inquiry Summit: A Practitioner's Guide for Leading Large-Group Change; Berrett-Koehler Publishers: San Francisco, CA, USA, 2009.

91. Meadows, D.H. Thinking in Systems: A Primer; Chelsea Green Publishing: White River Junction, VT, USA, 2008.

92. Koster, R.L.P.; Lemelin, R.H. Appreciative Inquiry and Rural Tourism: A Case Study from Canada. Tour. Geogr. 2009, 11, 256-269. [CrossRef]

93. Nyaupane, G.P.; Poudel, S. Application of appreciative inquiry in tourism research in rural communities. Tour. Manag. 2012, 33, 978-987. [CrossRef]

94. Raymond, E.M.; Hall, C.M. The Potential for Appreciative Inquiry in Tourism Research. Curr. Issues Tour. 2008, 11, 281. [CrossRef]

95. Bradbury, H.; Reason, P. Handbook of Action Research; Sage: Newbury Park, CA, USA, 2006.

96. Fitzgerald, S.P.; Oliver, S.P.; Hoxsey, J.C. Appreciative Inquiry as a Shadow Process. J. Manag. Inq. 2010, 19, 220-233. [CrossRef]

97. Van Der Haar, D.; Hosking, D.M. Evaluating Appreciative Inquiry: A Relational Constructionist Perspective. Hum. Relat. 2004, 57, 1017-1036. [CrossRef]

98. Reed, J. Appreciative Inquiry: Research for Change; Sage: Newbury Park, CA, USA, 2006.

99. Gössling, S.; Garrod, B.; Aall, C.; Hille, J.; Peeters, P. Food management in tourism: Reducing tourism's carbon 'foodprint'. Tour. Manag. 2011, 32, 534-543.

100. Wang, Y.; Huang, S.; Kim, A.K. Toward a framework integrating authenticity and integrity in heritage tourism. J. Sustain. Tour. 2015, 23, 1468-1481. [CrossRef]

101. Alkon, A. Black, White, and Green: Farmers Markets, Race, and the Green Economy; University of Georgia Press: Athens, GA, USA, 2012.

102. Britton, M. Fruit Growers await Seasonal Labour Force. Penticton Western, 21 February 2020.

103. Hall, C.M.; Scott, D.; Gössling, S. The Primacy of Climate Change for Sustainable International Tourism. Sustain. Dev. 2013, 21, 112-121. [CrossRef]

104. Quintal, V.A.; Thomas, B.; Phau, I. Incorporating the winescape into the theory of planned behaviour: Examining 'new world'wineries. Tour. Manag. 2015, 46, 596-609. [CrossRef]

105. Bruwer, J.; Gross, M.J. A multilayered macro approach to conceptualizing the winescape construct for wine tourism. Tour. Anal. 2017, 22, 497-509. [CrossRef]

106. Stone, M.J.; Migacz, S.; Wolf, E. Beyond the journey: The lasting impact of culinary tourism activities. Curr. Issues Tour. 2019, 22, 147-152. [CrossRef]

107. Andrews, G. The Slow Food Story: Politics and Pleasure; Pluto Press: London, UK, 2008.

108. Carolan, M. No One Eats Alone: Food as a Social Enterprise; Island Press: Washington, DC, USA, 2017.

109. Blay-Palmer, A.; Renting, H.; Dubbeling, M. City Region Food Systems: A Literature Review; RUAF Found. FAO: Rotterdam, The Netherlands, 2015.

110. Southerton, D.; Chappells, H.; Van Vliet, B. Introduction. In Sustainable Consumption: The Implications of Changing Infrastructures of Provision; Southerton, D., Chappells, H., Van Vliet, B., Eds.; Edward Elgar Publishing: Cheltenham, UK, 2004.

111. Karlsson-Vinkhuyzen, S.I.; McGee, J. Legitimacy in an Era of Fragmentation: The Case of Global Climate Governance. Glob. Environ. Policy 2013, 13, 56-78. [CrossRef]

112. Bramwell, B.; Lane, B. Getting from here to there: Systems change, behavioural change and sustainable tourism. J. Sustain. Tour. 2013, 21, 1-4. [CrossRef]

113. Higham, J.; Cohen, S.A.; Peeters, P.; Gössling, S. Psychological and behavioural approaches to understanding and governing sustainable mobility. J. Sustain. Tour. 2013, 21, 949-967. [CrossRef]

114. United Nations World Tourism Association. Policy Brief: Covid 19 and Transforming Tourism; WTA: Madrid, Spain, 2020.

115. Roman, M.; Niedziółka, A.; Krasnodębski, A. Respondents' Involvement in Tourist Activities at the Time of the COVID-19 Pandemic. Sustainability 2020, 12, 9610. [CrossRef]

116. Higgins-Desbiolles, F. Socialising tourism for social and ecological justice after COVID-19. Tour. Geogr. 2020, 22, 610-623. [CrossRef]

117. Haywood, K.M. A post COVID-19 future-tourism re-imagined and re-enabled. Tour. Geogr. 2020, 22, 599-609. [CrossRef]

118. Thompson Okanagan Tourism Association (TOTA). Summit 2020. Available online: https://www.totabc.org/summit (accessed on 5 February 2021). 